\title{
Reading Consumerism
}

\section{Sarah Elvins}

Matthew Schneirov,

The Dream of a New Social Order: Popular Magazines in America I893-1914

(New York: Columbia University Press 1994)

Jennifer Scanlon, Inarticulate Longings: The Ladies' Home Journal, Gender, and the Promises of Consumer Culture (New York: Routledge 1995)

Richard Ohmann, Selling Culture: Magazines, Markets, and Class at the Turn of the Century (New York \& London: Verso 1996)

It is not surprising that the popular magazine holds a certain fascination for scholars of late nineteenth- and early twentieth-century American history. In both form and content, mass-market magazines seem to embody the changes which were sweeping the United States: they were published on an unprecederted scale, they reached a national market, and they relied on revenue generated by advertising mass-produced goods for the bulk of their profits. Three recent works on American popular magazines examine how this medium not only mirrored developments in production, distribution and promotion, but took an active role in fostering a new American culture. Matthew Schneirov, Jennifer Scanlon and Richard Ohmann move beyond the history of the magazine industry itself to explore questions about the development of American consumerism, the nature of the middle class, and both the possibilities and limits of American economic and industrial expansion.

Matthew Schneirov's The Dream of a New Social Order examines what he terms the "magazine revolution" of the 1890s, which transformed the types of reading material available to middle-class Americans. While earlier generations had gained erudition from the "family house magazines" like the Atlantic and Harper's, new periodicals with a higher publication rate and much wider distribution were different not only in scale but in content. Schneirov alludes to the significance of publishing monoliths like the Ladies' Home Journal and the Saturday Evening Post in popularizing a new style of editorial and slicker, more 


\section{Left History 5.1}

advertising-oriented layout, yet he turns his attention to other, smaller outfits, in particular Munsey's, McClure's, and Cosmopolitan (a literary and news publication not related to the present-day women's magazine). These general-interest monthlies, he argues, were among the first to reach a national market, without being devoted to a particular group or subgroup of readers.(6)

Schneirov carefully tracks the content of these magazines over the years, looking for the common themes in articles and fiction which differentiated the popular periodicals from their genteel predecessors. He argues that the culture promoted by popular magazines revolved around three primary goals or "cultural dreams." The first was a vision of material abundance, in which life was made fulfilling by commodities and leisure time. The second was a faith in science and technology, in which the excesses of capitalism were eliminated by rational thought, increasing productivity and prosperity for all. The final dream was one of social justice, a goal taken up in the muckraking exposés of political corruption and industrial greed. (124)

But where did these dreams come from? Unlike other scholars of American mass media, Schneirov downplays the role of advertisers in shaping the social vision of popular magazines. Although he recognizes the increasingly important role that ad revenue played in the operation of these businesses, he insists that advertisers at the turn of the century were not organized or sophisticated enough to dictate to magazines, the only national market. (10) Schneirov's analysis is very much rooted in the creators of the magazines - he looks at the intentions of writers and editors like John Brisben Walker (of Cosmopolitan), S.S. McClure and Frank Munsey and argues that these men aimed to help their readers engage in the "whirlpool" of modern life. Schneirov contends that the magazines promoted a new national sensibility that had deeper roots than the rise of consumerism or a reaction against industrialism. He contends that these pioneers of national mass communications "thought of themselves as contributing to a new social order." (255)

Schneirov builds a convincing case that the writers and editors of these particular magazines shared common assumptions about nationhood, race and modernity. Less clear, however, is the role of the reader in accepting or rejecting their cultural dreams. The publishers and writers he has selected may very well have articulated a new social vision, but Schneirov never fully demonstrates how and why " $[\mathrm{m}]$ any readers of popular magazines were eager to learn from these modern prophets." (244) Similarly, he is persuasive when he notes that his cultural entrepreneurs "saw the need to unite various social classes and interest groups," (201) yet provides no evidence to back his claim that popular magazines were attracting new readers from the white-collar working class. (97) 
Where Schneirov outlines the cultural message promoted by the editors of general interest magazines to both male and female readers, Jennifer Scanlon focuses on the relationship between women, magazines and consuming. In Inarticulate Longings, Scanlon uses the Ladies' Home Journal to explore the gendered nature of American consumer culture. Advertising plays a more central role in her analysis than it does in Schneirov's work. Scanlon demonstrates that the white, middle-class readers of the Journal were viewed as the ideal market for national advertisers in an era before market segmentation. The magazine encouraged women to make the most of modern life by taking full advantage of the commodities available to them.

Scanlon begins her study with a comparison of two issues of the magazine from 1914 and 1924, carefully detailing changes in the types of articles, the layout and the editorial slant over ten years. One of the strengths of Scanlon's work is in her recognition of the interconnected nature of advertising and editorial material in the magazines. Although this may seem an obvious point, Scanlon considers the articles and ads of the Journal simultaneously, just as a reader flipping through the magazine did. Where Schneirov examined the content of articles culled from many volumes of a particular monthly, Scanlon demonstrates how the placement of ads within a single issue could serve to reinforce or to mitigate the content of articles. Her description of how processed food manufacturers first succeeded in having their ads placed near stories which featured their products and later took over the role of providing recipes to readers provides new insight into the changing relationship between advertisers and the editorial staff at the Journal.

Scanlon does a good job of imagining what the experience of reading the magazine was like - from noting that short articles could be read in between household tasks, to considering which readers would be best served by the advice given in the Journal's regular columns. She might, however, have gone even further in emphasizing how the desire to generate ad revenue often dictated editorial practice. Consider, for example, her take on the practice of "tailing" articles. Scanlon argues that dividing stories or features so that they conclude with smaller columns toward the end of the magazine achieved a sort of visual balance within each issue of the Journal:

This is satisfying for the reader, for the text on the earlier pages is more likely to have drawings that accompany it than is the later text, which is often simply the endings of articles and stories begun earlier on. Advertisements provide the visuals for the latter part of the magazine. (30) 


\section{Left History 5.1}

She fails to note that this practice was most satisfying not for the reader, but for advertisers, who were guaranteed that readers seeking the end of a novel instalment or advice column would be forced to examine the back pages, which might otherwise have gone ignored. In this manner, publisher Edward Bok could assure manufacturers that all pages in his publication were prime locations for advertisements. If anything, the reader was inconvenienced by having to page through the entire magazine, rather than read each article in simple sequence.

Scanlon's interpretation of the Journal's policy toward product endorsement also raises some questions. She notes that contributors like "scientific housekeeping" advocate Christine Frederick were discouraged from mentioning specific brands in their columns. Scanlon argues that "the Journal deemed the outright endorsement of products incompatible with writing advice columns in the magazine." (70) A different reading, however, suggests that, far from resisting product endorsement as ethically questionable, Journal publisher Cyrus Curtis felt that in selling advertising space to a particular manufacturer, he was putting the full approval of the magazine behind its wares. Christopher Wilson has noted how Journal editors viewed their role as winning the trust of their audience - to have readers accept the advice offered in both articles and advertisements. The editors went so far as to guarantee their subscribers against loss from any advertisement found in the magazine. ${ }^{1}$ The 1910 adoption of the "Curtis Advertising Code" similarly promised to protect readers from outlandish claims, and specifically banned the promotion of unseemly wares like tobacco, playing cards, patent medicines and alcohol from the pages of the periodical. ${ }^{2}$ Readers could rest assured that the editorial staff had excluded "inferior" or inappropriate wares, while advertisers could bask in the glow of reputability that came with "Code" endorsement. (To this day, Good Housekeeping magazine offers a "Seal of Approval" to products which meet its standards for good value, and presumably, advertising placement). Given this complicated relationship between the magazine and the goods it promoted, perhaps objection to the mention of particular products in articles stemmed more from a desire to keep all Journal advertisers happy, than from any moral squeamishness about blending the editorial and advertising departments of the magazine.

Aside from these minor technical points, however, Scanlon presents a compelling analysis of the contradictory nature of the Ladies' Home Journal. She argues that the magazine was neither a tool of patriarchy nor a vehicle for women's liberation. Instead, it illuminates the limits of American womanhood during the early twentieth century, while demonstrating the potential for change. 
Even as it promoted traditional notions about femininity, the Journal "helped sow the seeds for women's later demands for autonomy and self-definition." (2) Indeed, nowhere are these two contrasting purposes more evident than in Scanlon's presentation of the lives of Journal contributors and female advertising agency employees. Scanlon demonstrates how female writers like Juliet Virginia Strauss struggled to reconcile their own lives with the ideal of middleclass womanhood they espoused in their columns. (103) Even as she advocated the "simple life" of wife and mother for other women, Strauss pursued her own career outside of the home. The members of the Women's Editorial Department at the J. Walter Thompson Company (the largest ad agency in the country during this time period) similarly gained independence by encouraging the consumerism of other women.

Of the three works reviewed here, Richard Ohmann's is the most comprehensive, and probably of most use to those more interested in cultural and social history than the magazine industry per se. Ohmann's great strength is his ability to put his subject in context: he seamlessly links the history of mass magazines at the turn of the century to the changes in retailing, distribution, manufacturing, advertising, city planning, and transportation during this time. But the real story here is the emergence of the professional-managerial class, or PMC, as he refers to it throughout the book. In contrast to Schneirov, Ohmann keeps his readership in sharp view throughout his analysis. He carefully traces the growth of the PMC, its tastes in homes and in fashions, its jobs and its preoccupations. Massproduced goods were one flag used by middle-class members to signal their status. Ohmann argues that magazines not only helped to promote other goods, but were brand-name commodities themselves: "their consumption, too, conferred distinction." (174)

Ohmann's examination of the changing social space of the PMC adds new nuance to the conception of the magazine as a national medium. He demonstrates that while these magazines may have been sold across the United States, geographic representation in the magazines was not so democratic. Stories concentrated on the eastern scaboard, particularly New York City, with occasional references to California or Chicago. He notes:

Iowa was not a visible place, Arkansas was not a place, Montana was not a place, though one of them might momentarily and as it were accidentally come into view, as when an article on amateur photography included three scenes from Minneapolis. (231) 


\section{Left History 5.1}

Descriptions of leisure time in Sag Harbor, Boston, or Europe "invited PMC readers to know vicariously a circuit of places" inhabited by the rich and fashionable. (232) Ohmann argues that these shared references flattered readers into feeling that they were in touch with the social scene even if they lived far from it. Knowledge of the "right" events, like the ability to choose amongst brand-name goods, helped solidify the reader's sense of membership within the growing middle class.

Just as certain places were excluded from coverage in the popular press, groups outside of the PMC did not receive the attention of the monthlies. Ohmann compares the almost total silence on the issue of race in America during this time with the considerable coverage given to the "Woman Question." He notes that blacks had ceased to exist as a political bloc by the 1880 s, and most lived and worked in a world apart from the white middle class. At the turn of the century, debate over race relations seemed "increasingly irrelevant to the social project of industrial capitalism and to the PMC vision of modernity." (258) Ohmann argues that the use of black figures in advertising for household products further suggests how magazines tacitly and almost unthinkingly presented all modern social space as white. In contrast, white female readers were identified as part of the PMC project, and thus could not be excluded from the medium in the same manner.

Ohmann argues that magazines like Cosmopolitan and the Ladies' Home Journal helped readers to "fix their bearings in the fluid social space" of the time. (220) In his final chapters, he turns to the subject of magazine fiction, exploring how even sentimental fantasies helped readers consolidate their middle-class identity. These formulaic comic romances, he argues, can be understood as part of a continuing dialogue of class. Both partners in courtship tales were almost invariably young PMC members, who embraced the possibilities of modernity and rejected the old order of the nineteenth-century elites. Only rarely do characters fall in love with people from working-class or immigrant backgrounds, and in these cases, Ohmann demonstrates, suitors invariably find some means (education, business acumen) to ascend to professional status. (320) His careful mapping of the boundaries of this genre shows how fiction worked in tandem with magazine articles and advertisements to orient readers in the changing space of industrial capitalism.

One of the reasons why historians have found these magazines so intriguing a source is their status as "popular" media: they seem significant by definition, simply because they reached a large segment of the America population. But how do we explain popularity? Did editors dictate public taste, or were the magazines at the mercy of market forces? Schneirov centres on the cultural 
agenda of the magazines' creators, while uneasily considering that the need to attract readers, and in turn advertisers, "required an engagement with contemporary popular interests, from concerns about health to popular fears of concentrated corporate wealth and corruption to new women's roles." (257) Scanlon uses the letters sent in to the Ladies' Home Journal to explore how the magazine increased its appeal by responding to requests from readers. Ohmann's profile of an emerging class perhaps comes closest to reconciling the tension between industrial capitalism's need to promote a lifestyle centred on commodities and the individual's role in choosing to participate in a world of goods. Despite some minor caveats, each of these works contributes to our understanding of American mass culture and consumerism.

${ }^{1}$ Christopher P. Wilson, "The Rhetoric of Consumption: Mass-Market Magazines and the Demise of the Gentle Reader, 1880-1920," in Richard Wightman Fox and T.J. Jackson Lears, eds., The Culture of Consumption: Critical Essays in American History; 1880-1980 (New York 1983), 60.

2 John Tebbel and Mary Ellen Zuckerman, The Magazine in America 1741-1990(Oxford 1991), 97.

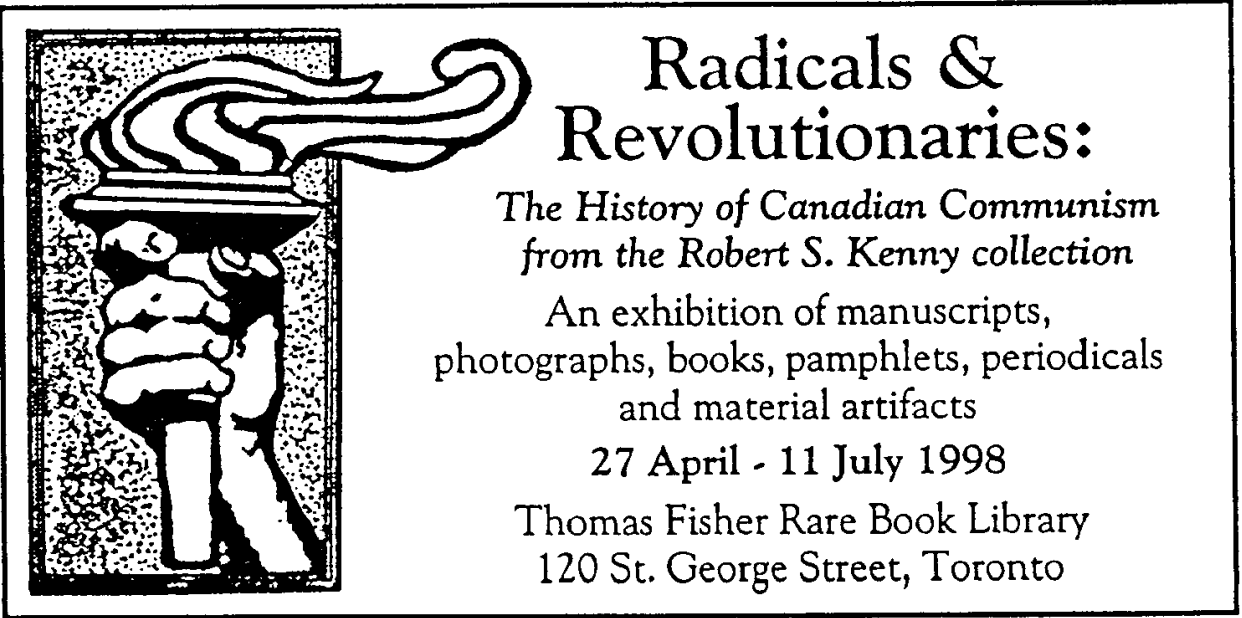

